\title{
Lost passports? Disconnection and immobility in the rural and urban Solomon Islands
}

Passeports perdus ? Déconnection et immobilité en milieu rural et urbain aux îles Salomon

\section{Debra McDougall}

\section{(2) OpenEdition}

\section{Journals}

Electronic version

URL: http://journals.openedition.org/jso/7764

DOI: $10.4000 /$ jso. 7764

ISSN: $1760-7256$

\section{Publisher}

Société des océanistes

\section{Printed version}

Date of publication: 15 December 2017

Number of pages: 63-76

ISSN: 0300-953x

\section{Electronic reference}

Debra McDougall, "Lost passports? Disconnection and immobility in the rural and urban Solomon Islands", Journal de la Société des Océanistes [Online], 144-145 | 2017, Online since 15 December 2019 connection on 15 March 2021. URL: http://journals.openedition.org/jso/7764 ; DOI: https://doi.org/ $10.4000 / j 50.7764$

\section{cc) (†) $\odot$}

Journal de la société des océanistes est mis à disposition selon les termes de la Licence Creative Commons Attribution - Pas d'Utilisation Commerciale - Pas de Modification 4.0 International. 


\title{
Lost passports? Disconnection and immobility in the rural and urban Solomon Islands
}

by

\author{
Debra McDOUGALL*
}

\begin{abstract}
Anthropologists have documented the dense "transisland" ties between rural and urban life in contemporary Melanesia. In exploring dilemmas of mobility and belonging in Solomon Islands, this article focuses on anxieties about the ways that these geographically expansive networks are shrinking - anxieties expressed through jokes and laments about "losing passports". Drawing on interviews and published memoirs, it tracks the stories of two Malaitan families who migrated for economic opportunities in the late 1950s: one followed a well-trodden path to the Western Solomons to work on a copra plantation on Ranongga; the other family followed new paths to the rapidly developing the post-World War II capital, Honiara. Playing out against the backdrop of the so-called "Ethnic Tensions" (1998-2003), these narratives underscore the importance of maintaining ties to an ancestral home, but also the degree to which these networks are becoming attenuated.
\end{abstract}

KEYwords: Honiara, Solomon Islands, migration, land tenure, conflict, rural-urban ties

As colonial outposts have become indigenous cities in Melanesia, anthropologists have documented the interpenetration of urban and rural life worlds. Writing of Vanuatu, for example, Lamont Lindstrom describes the frequent movement of people and resources between a village on Tanna Island and the capital city, Port Vila. Urban residents live "trans-island" lives (2012: 2) as they:

\section{RÉSUMÉ}

Les anthropologues ont documenté les intenses liens inter-îles qui existent entre la vie rurale et la vie urbaine en Mélanésie aujourd'hui. Tout en explorant les dilemmes causés par la mobilité et l'appartenance aux îles Salomon, cet article met l'accent sur l'anxiété associée au rétrécissement de ces réseaux, anxiété qui s'exprime à travers différentes blagues et plaintes à propos de la "perte du passeport". En utilisant des entretiens et des mémoires publiées, l'article suit les histoires de deux familles de Malaita qui ont migré pour des raisons économiques vers la fin des années cinquante. La première a suivi le chemin souvent emprunté vers les Salomon occidentales pour y travailler sur une plantation de coprah; l'autre s'est dirigée vers la capitale Honiara qui se développait rapidement après la Deuxième Guerre mondiale. Sur fond de tensions ethniques (1998-2003), ces histoires soulignent l'importance du maintien des liens avec la terre ancestrale, mais aussi l'érosion de ces réseaux.

Mots-clés : Honiara, îles Salomon, migration, tenure foncière, conflit, relations ruraux-urbains

"maintain deep and enduring ties with home villages, and they still organize and identify themselves according to these original villages and islands." (2011:257)

Similarly, writing of Port Moresby in Papua New Guinea, Michael Goddard describes Melanesian urbanity as "bilocal", suggesting that:

“[a] constant movement between town and 'village' marks the hybridity of PNG societies, in contrast with 


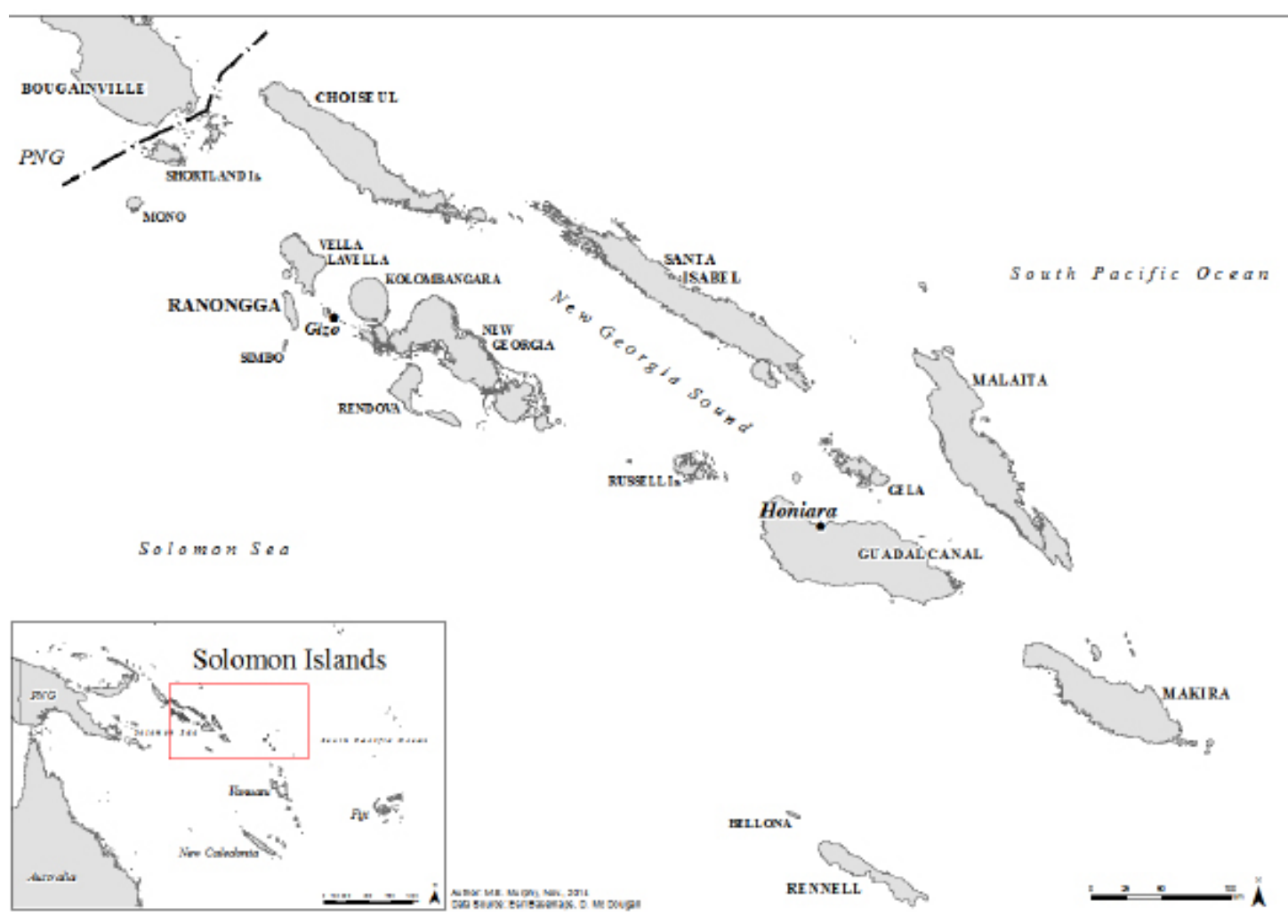

Map 1. - Solomon Islands (M. E. Murphy, Nov 2014, Esri Basemaps, D. McDougall)

the putative dichotomy of a modern urban society and a traditional rural society, or alternatively the rural-urban continuum" (2010a: 11)

Ben Burt calls our attention to the same phenomenon in Solomon Islands capital Honiara, suggesting that Kwara'ae people

"seem to treat their experience of town and rural life, of Western and local culture, as contrasting aspects of a single world, inextricably linked." (Kwa'ioloa and Burt, 1997: 8)

Such studies of contemporary urban Melanesia resonate with the so-called "transnational turn" in migration studies (see, e.g., Glick-Schiller et al., 1991) - a parallel made evident by Lindstrom's use of the term "trans-island" to describe the expansive connections of urban Tannese. Rather than either/or models of migration, where migrants are either assimilated to the host society or remain attached to the society of origin, transnational approaches to migration focuses on possibilities of sustained relationships to more than one place and more than one network of people. In Oceania, where the sea has long connected people across vast distances, there is something distinctly traditional about this translocal sociality. As Lindstrom writes of Vanuatu, contemporary urbanites who live across the rural-urban divide are

"drawing on longstanding island skills of incorporating old and new others, and old and new places, within their everyday lives and within the compass of ordinary personhood and place-making." (2012: 5)

The stories of urban migrants in Melanesia echo those of modern migrants everywhere. Many intend to stay just a few years to earn money before returning "home." But as decades pass, children and grandchildren are raised with no lived connection to the places, people, and language of the origin society. Yet, urbanization in Melanesia - especially Papua New Guinea, Solomon Islands, and Vanuatu ${ }^{1}$ - is distinctive in at least two ways. First, local people and outsiders alike assume that every indigenous resident has an ancestral home. To be a citizen - indeed, even to be a person - is to be a landowner. This means that the sort of disconnection from ancestral land that so often characterizes migrant trajectories

1. The term "Melanesia" draws an arbitrary line in the Pacific (with Fiji problematically between Polynesia and Melanesia), taking skin color as the primary indicator of difference. Nevertheless, the term has been adopted by leaders and islanders themselves. My focus here is Vanuatu, Papua New Guinea, and Solomon Islands, which share important features. I do not discuss Fiji, with a large population of descended from South Asian indentured workers and traders, New Caledonia, which remains a French colony, or West Papua, which is within the state of Indonesia. 
has ontological as well as economic implications. The second distinctive factor is the near absence of international migration. In contrast to other Pacific Islands countries like Samoa, Tonga, or Marshall Islands, which have very high proportions of their total population overseas (Hugo and Bedford, 2013: 12), Melanesian states have among the lowest rates of emigration in the world: $0.2 \%$ for Papua New Guinea, $0.3 \%$ for Solomon Islands, and $0.9 \%$ for Vanuatu (Curtain et al., 2016: 3). It is hard to understand the challenges of urban life and the fraught relationship between town and village without remembering that once they have moved to town, urbanites have few options for further mobility.

This article explores dilemmas of mobility and belonging in Solomon Islands. I focus less on expansive "trans-island" forms of belonging and more on anxieties about the ways that these geographically expansive networks are shrinking. Beginning during the tumultuous period of civil conflict known as "the Ethnic Tensions" or "the Tensions," my field research has focused primarily on the rural island of Ranongga in Western Province, where I lived for 13 months in 1998-1999 and 10 months in 2000-2001. I returned to Ranongga for further research during the post-conflict era $(2005,2006-7,2010$, and 2016), and also spent more time with Ranonggans in the Western Province capital of Gizo and in the national capital of Honiara on Guadalcanal. In this paper, I do not write about Ranonggans per se, but about the experiences of people originally from the island of Malaita in the eastern Solomons. Malaita is Solomon Islands' most populous province. Starting in the nineteenth century and continuing through the twentieth century, Malaitan men (like many other Solomon Islanders) have undertaken labor overseas or elsewhere in the Solomon Islands. Today, Malaitans comprise a large majority of the population of Honiara and have migrated to other regional centers, including Western Province capital Gizo and its main commercial center Noro. ${ }^{2}$ At the core of the article are the stories of two Malaitan families who migrated for economic opportunities in the late 1950s: one followed a well-trodden path to the Western Solomons to work on a copra plantation on Ranongga; the other family followed new paths to the rapidly developing capital, Honiara. The first case is drawn from interviews conducted on Ranongga in 1999 and the second is drawn from the memoirs of Michael Kwa'ioloa (Kwa'ioloa and Burt, 1997, 2012), a long-term resident of
Honiara. ${ }^{3}$ There are striking similarities in how these families sought to establish ties to their new homes as well as significant differences in the nature of the challenges faced by urban and rural families.

The Ethnic Tensions are the backdrop for both of these cases. ${ }^{4}$ In 1998, an indigenous insurgency on the island of Guadalcanal, where Honiara is located, sought to violently evict Malaitan settlers from rural and peri-urban areas. In 1999 and early 2000, tens thousands of settlers fled Guadalcanal to return to their home provinces. This triggered the formation of a Malaitan countermilitia, violent inter-ethnic conflict, and a period of state collapse that lasted until 2003, when an Australian-led international intervention ended the conflict. Even before this intervention, most of those who had fled the conflict returned to Honiara, many with a heightened understanding of the precarity of their situation as guests on other people's land. This period underscored the importance of maintaining ties to an ancestral home, but it also made many aware that these connections were more tenuous than they had imagined.

\section{Lost passports}

My starting point for understanding anxieties about connections to rural and urban homes are jokes and laments about "losing passports" (the phrase is in Solomon Islands Pijin is lusim pas$p o t)$ that seem to have wide circulation. Although relatively few people of Melanesia have the opportunity to travel overseas, ordinary villagers are familiar with the artifacts and processes involved in such travel and deploy them symbolically even when they not actually possess them. A passport simultaneously identifies the holder as a person of a particular place and gives her permission to move beyond the place. Passports are granted only to those recognized as a legitimate citizen. Without a passport, you are stuck - if at home, unable to leave travel abroad; if abroad, unable to return home.

Talk of passports is not limited to airports or immigration offices. A striking example of passport talk comes from the Bilua, in southern Vella Lavella Island in the Western Solomons. Anthropologist Sarah Krose reports that when she travelled between villages, she was told to carry a particular aromatic leaf said to disguise the smell of foreigners. As is the case throughout the region, ancestral spirits sense the presence of

2. Important recent discussions of Malaita in the broader context of Solomon Islands history include Akin (2013), Allen (2013), Burt (1994), Keesing (1992), Moore (2017).

3. These cases are also discussed in McDougall, 2016, Chapter 7. The present article expands on analysis in this earlier work.

4. See Fraenkel (2004) and Moore (2004) for book length overviews of the Tensions and Allen (2013) for militant's perspective on the conflict. 
trespassing strangers and are understood to cause them disorientation, illness, or even death. Her Bilua acquaintances called this leaf her "passport" or "ticket" (2015: 191-192).

My interlocutors on nearby Ranongga Island used the idiom of the "passport" to talk about connections to ancestral lands. One incident documented in my field notes concerned a woman from Santa Isabel who had lived for nearly twenty years in her Ranonggan husband's village. She would say that she had "lost her passport" and had to stay in Ranongga; other women teased her in a good-natured way in the same terms, saying she was a "citizen" of the village. As it turned out, she hadn't lost her passport: a few years after I heard this joking, I learned that she had taken her entire extended family - including children and grandchildren who had lived all of their lives on Ranongga - home to Santa Isabel. They have remained there for a decade, re-establishing connections to her natal home. Sometimes, connections to ancestral homes are renewed across many generations, as the children of war captives taken from seek out their long-lost relatives from distant islands (see McDougall, 2016: 188).

The most extended and theoretically insightful discussion of the idiom of the "lost passport" comes from Daniela Kraemer (2013), who carried out research among young people in the multiethnic Freswota neighborhood of Port Vila in Vanuatu. When she conducted an informal survey, all respondents claimed an ongoing connection to a rural island home. As she got to know a cohort of young men well, however, Kraemer gradually realized that they lacked the knowledge and relationships that would allow them to ever return to the villages of their parents. They lamented that they had "lost passports" to their ancestral homes. They are immobilized not only in relation to the origin places of their parents or grandparents, but also in relation to central Vila, where they are excluded from the main "systems" of the town because of their minimal formal education (2013: 26-27, 98-101). In Kraemer's interpretation, the idiom of the "passport" points not only to practical possibilities of movement, but also to an existential condition:

\footnotetext{
"the ni-Vanuatu person's inalienable right to ground and to absolute autochthony." (2013: 95)
}

She argues that having recognized that they have no ancestral ples, the young men are also seeking to transform Freswota into such a ples. Until they establish new roots, these young men do not feel they will be able to move beyond the confines of the neighborhood. ${ }^{5}$

Kraemer's analysis highlights the way that insecure belonging and constrained mobility are flip sides of the same coin. This theme emerges in Michael Goddard's writing about Port Moresby (2005, 2010a, 2010b). He argues that urbanization in Melanesia has long been seen as pathological because change is too swift (villagers suddenly confronted by surprising new urban ways of life) and movement too extensive (people are moving all over, into spaces where they do not belong); for many, however, stagnation and immobility - not rapid change and hypermobility - characterize urban life. Motu-Koito people, who are the traditional owners of the land on which Port Moresby is built, have not been displaced from their land, but entrapped by encroaching settlements. Up to the Second World War, settlements were flexible and mobile, but people now feel hemmed in and overrun (2010b: 29; Goddard 2005). This sense of being stuck in place is shared by residents of urban and rural places alike. Writing of Vula'a people in southeastern Papua New Guinea, Deborah Van Heekeren reports a comment by a young woman frustrated by high transportation costs - they would forever be "citizens of the village" (2010: 67). The lack of geographic mobility resonates with a broader sense of stasis. Van Heekeren observes,

"It is not 'social change' that today affects the Vula'a but, rather, a sense of stagnation. The promise of 'progress' has been replaced by the reality of 'regress', as people come to terms with their role as 'citizens of the village." (2010: 70)

Conversely, for a range of reasons, Vula'a people living in Port Moresby find it more and more difficult to return home (2010: 54-55).

Few citizens of Solomon Islands, Vanuatu, or Papua New Guinea have the opportunity to migrate overseas. Yet, the idioms they use to talk about their movements within the nation - becoming "citizens" of new places, or "losing their passports" to old places - evoke forms of movement that would take them beyond the territorial boundaries of the nation state. Such discourse is not surprising in light of long histories not only of moving between islands, but also across international boundaries.

\section{Thwarted mobility: history of Solomon Islands migration}

In order to understand this sense of stagnation, as well as the challenges facing the migrant $\mathrm{Ma}$ laitan families discussed below, it is necessary to have some sense of the history of migration and urbanization in Solomon Islands. As noted above, Solomon Islands - like Vanuatu and Papua New Guinea - have very low rates of international emi-

5. For a discussion of the ways that urban youth are establishing similar roots in Honiara, see Jourdan (1998). 
gration. Part of the reason for this lies in the fact that people of these countries have mostly retained access to the resource rich and relatively plentiful land and seas of their ancestors; they do not need to migrate to survive. A more important factor in constraining international mobility has been policies and regulations imposed from beyond Solomon Islands, especially by Australia. As Craig et al. (2014) conclude, Solomon Islanders have eagerly taken advantage of whatever possibilities for migration have been available to them.

In the late nineteenth and early twentieth century, tens of thousands of Solomon Islanders, along with men from Vanuatu and Papua New Guinea, signed indenture contracts to work in the cane fields of Fiji and Queensland. Although Solomon Islands population has increased exponentially over the past century, the diaspora was greater in both relative and absolute terms at the turn of the twentieth century than the turn of the twenty-first century, although the local population has increased exponentially (Craig et al., 2014: v). Australia's White Australia policy, specifically the Pacific Island Labourer's Act 1901, led to the deportation of some 5,000 Solomon Islanders, some of whom had lived for many years in Queensland (Corris, 1973: 130). At this point, international mobility was replaced by mobility within the territorial confines of the colonial administration. The British Solomon Islands Protectorate, which had been declared in 1893 and established in 1896, was desperate to create a selfsufficient administration through tax revenue, but faced constant labor shortages in the copra industry and worked hard to pull local men into wage labor (see Bennett, 1987: 150-191).

The internal labor migration of the twentieth century helped to establish the ethnic animosities that emerged in virulent form in the period of Ethnic Tensions (Moore, 2007). People living in areas that became centers of European colonial development, including much of what would become the Western Province, could earn money through small-scale copra production themselves, and few chose to endure the harsh discipline and poor conditions of plantation labor. Men of the southeastern Solomons, and above all the densely populated island of Malaita, worked as laborers. Extra-local recruitment was an intentional strategy: as Murray Bathgate observed for northern Guadalcanal, plantation managers recruited outsiders rather than local laborers in order to "guarantee a captive work force for the period of contract" (1985: 92). In some areas, participation in interisland labor was very high. At the Protectorate's first census, 10 percent of the total population of Malaita was laboring away from the island (Akin,
2013: 94); Bennett's surveys on the southern coast of Guadalcanal in the 1970s showed that virtually all men had worked for years away from their home areas (Bennett, 1987: 189). The ongoing viability of subsistence agriculture in cash poor areas - today lauded in the development literature as an example of rural "resilience" (see McDougall, 2015) - was a constant irritation to both planters and the colonial government, because the fact that workers could always go home limited the level of exploitation they were willing to endure.

Patterns of mobility changed after World War II, as Honiara was built as the capital of the British Solomon Islands Protectorate on the site of the American military base on Guadalcanal. Like other Melanesian towns, it began as a European enclave; colonial administrators assumed that generations would pass before Islanders could govern themselves. As the focus of significant inputs of British development aid in the late 1950s (Bellam, 1970), Honiara drew workers from all provinces, including a high proportion from Malaita. Honiara is not the only urban area in the Solomons, and provincial towns like Auki in Malaita Province (approximately 5,000 residents), and Gizo, Noro, Munda, and Nusa Roviana in the Western Province (with populations of 3,500, 3,300,1,315, and 1,528 respectively) are also growing rapidly (Solomon Islands Statistics Office, 2012). None, however, comes close to Honiara in population size or scale of commercial activity. Honiara's population was estimated at 65,000 in the 2009 census, though recent surveys suggest a population of more than 100,000 (Solomon Islands Statistics Office, 2012; Moore, 2015: 420, footnote 1).

In an era of accelerating global mobility, Solomon Islanders and other Melanesians continue to find their possibilities for international movement severely constrained. Current neoliberal regimes of international migration are characterized by a "global competition for skills" that opens opportunities for skilled migrants, but strictly constrains opportunities for unskilled migrants, particularly those who do not already have overseas connections through a diaspora (Craig et al., 2014: 4, 1619). Seasonal worker programs were formalized in New Zealand in 2005 and Australia in 2012; these schemes allow Pacific Islanders to undertake agricultural labor on short-term contracts. Some analysts argue that these schemes open new avenues of social mobility, particularly for ni-Vanuatu workers whose participation has increased dramatically since the introduction of the scheme (Bailey and Wells, 2017); others argue that the development benefits of such short-term contracts are limited (Curtain et al., 2016: 14). ${ }^{6}$ Nevertheless,

6. Recently, there have been startling reports of exploitation of Pacific Islands workers on Short Term Worker schemes in Australia (Hermant, 2016; Doherty, 2017). In tactics that hearken back to the days of indentured labour, some employers appear to be deducting so much for accommodation and other expenses that workers earn nothing at all. 
there appears to be a growing consensus that out-migration must be part of the development vision of Melanesian countries: some viewing emigration as a "safety valve" for societies with a youth bulge and slow job growth (Ware, 2005) and others some focusing on the importance of diaspora communities in supporting the home country (Curtain et al., 2016).

With nearly zero net emigration overseas (Bedford and Hugo, 2012; Hugo and Bedford, 2013; Ware, 2005), only about 16 new formal sector jobs for every 100 entrants to the labor market (Curtain et al., 2016: 7), minimal possibilities for expanding Honiara onto customary land (Foukona, 2015; Monson, 2015; Moore, 2015), and minimal focus on urban development in the policy plans of Solomon Islands government and the donor community (Evans, 2015; Keen and Barbara, 2016), economic prospects for ordinary people in Honiara seem unpromising. Yet people continue to arrive. All roads seem to lead to Honiara, but there they end in a roadblock. ${ }^{7}$

\section{Case 1: Becoming citizens of Ranongga}

Before turning to the particular challenges of urban life, I discuss the situation of a family who followed older patterns of migration to a plantation in Western Province. As noted above, the Western Province was a destination for labor migration throughout the twentieth century. With ample land and sheltered lagoons, and a missionized and peaceful population, it was a center of the copra industry. Most laborers came from the island of Malaita, and to this day, there are settlements named "New Mala" around the province. Ranongga's New Mala was established in 1959 by a man named James Suafo. Suafo and his family spoke to me some forty years later, in 1999. They told of gradually attenuating connections to Malaita as they came to be at home in Ranongga, welcomed by landowners. This sense of connection was threatened, however, by increasing expressions of hostility toward Malaitans in the era of the Ethnic Tensions that resonated far beyond Guadalcanal. James Suafo was born in North Malaita sometime in the 1910s. He said he was already big when his father joined in the punitive expedition that followed the murder of District Officer W. R. Bell by Kwaio warriors in 1927 (Keesing and Corris, 1980; Akin, 1999). In the late 1940s and early 1950s, James recalled, he worked as a clerk in the post-war Maasina Rule movement. After Maasina Rule ended, he worked as a tax collector for the government, but the wages were poor. Kitche- ner Wheatley, the son of English trader Norman Wheatley, was looking for men to work on a copra plantation on northeastern Ranongga, and James eagerly signed on. He led a team of twelve Malai$\tan$ men to a tract of alienated land on Ranongga's then sparsely populated northeastern coast. James and his crew worked for six months at a time, with his wife and children back home in Malaita. In 1966, he learned that his eldest daughter, then ten years old, became the fifth of their children to die. James decided to bring his wife and surviving children along with a niece and her husband to settle at the site he named New Mala.

The move was to be temporary. "We wanted to go back," he explained to me, but said that Wheatley's children "held us here." He admitted that life on Ranongga was good: "Many of my brothers in Malaita are already dead, but here some people are old men before they die. That's why we stay here. And because the people here love us too." James and his family talked about how Malaita was in their bodies; custom is something that you take no matter where you go (see also Gegeo, 2001). At the same time, they said they were living "underneath" Ranonggan custom: "the custom of this place holds us." James' niece had returned to see her aged mother, but only one of her seven children had set food on their mother's home. One of the adult grandchildren added that that they had no connection to Malaita and were "like citizens" of Ranongga. In telling their stories, James and his family recounted events that I later came to recognize as clear assertions of belonging and connection. A niece spoke of how good Ranonggan women were to her, repeatedly mentioning that they had helped her in childbirth and with her children. She named her daughter after the daughter of one woman who had cared for her after the birth. James recalled his work in clearing the land for the plantation. When he arrived in 1959, he said, the place was just big bush, completely overgrown. He had spilled his sweat and that was why both Kitchener Wheatley and the people of Ranongga wanted him to stay. In Ranongga, and throughout island Melanesia, clearing primary forest is a powerful assertion of ownership. James was not claiming any kind of primary right, however, because after describing his work in clearing the land, he explained that he was careful to "ask" for any land that he used for gardening or settlement - thus explicitly acknowledging the prior rights of the Ranongga people who had lived there before. He explained that "the people of this place" were good and generous and never denied his requests.

7. That few people migrate overseas is clear. What is not clear is how many people move from Honiara to other regional cities or rural areas. People of resource rich and less densely populated Western Province feared being swamped by people of Malaita province who are crowded out of Honiara, including those who have married into Western Province families. 
When I asked about the formal status of the land on which New Mala was built, James explained the somewhat complex history of the lease acquired by Kitchener Wheatley. But then he added that it wasn't really Wheatley who owned the land:

"The land belongs to the people here. It was only the government who gave it to Wheatley."

The land is formally alienated, but James and his neighbors treat it as though it is still customary land.

My visit to New Mala took place at a time when thousands Malaitans were being evicted from Guadalcanal; a few weeks after our interview, anti-Malaitan violence around the Western Province towns of Noro and Munda was directed largely at Malaitans who had settled on the officially alienated land abandoned by expatriate plantation owners just as James and his family had (Scales, 2007: 194). Yet, James and his family expressed sympathy for Guadalcanal people. Malaitans settled on Guadalcanal or Western Province had no right to bring their relatives from Malaita with them. "Guadalcanal people," he said, "have a right to be angry." James was also careful to point out that they had never invited other relatives from Malaita to join them in New Mala, a point that Ranonggans living in surrounding villages mentioned approvingly when they told me of their high regard for old James. Although they felt "like citizens," it was clear that James and his family were worried about the future, hoping that the next generation of Ranonggan leaders would be as generous as the current generation.

Animosity between people of Western Province and migrants from Malaita date to the early twentieth century, when large numbers of $\mathrm{Ma}$ laitans came to work on Western Province plantations. Labor migration brought Malaitans and Westerners into close proximity without opening many opportunities for real engagement. Outsiders brought workers onto local land without asking permission from the indigenous inhabitants; it was an inherently antagonistic situation. Yet stories like James' illustrate the fact that even in the inherently antagonistic situation of labor migration - where a complete outsider invites migrants onto land that local landowners see as their own - hostility is not inevitable. Both landowners and migrants work to act as hospitable hosts and gracious guests (McDougall, 2016: 199-2001). And the guests can slowly come to identify as people of their adopted homes.

\section{Case 2: Maintaining connections home in Honiara}

The second case I discuss is drawn from two volumes of memoir and reflection by Michael Kwa'ioloa, written with anthropologist Ben Burt. ${ }^{8}$ The first book, Living Tradition: A changing life in Solomon Islands (1997), documents his upbringing in rural Malaita and his activities in Honiara. The second book, Chief's Country (2012), continues the narrative of his life through the period of the Ethnic Tensions. Spanning a period of rapid change as Honiara was transformed from a colonial backwater to a bustling and troubled Indigenous city, and documenting the plight of migrants to Guadalcanal in the period of the Ethnic Tensions, these works are a window into the processes through which a "trans-island" or "bilocal" family has sought to maintain connections home and establish itself in Honiara.

Born in 1953, Kwa'ioloa grew up in rural Kwaràae, a language group in northeastern Malaita. At about the same time that James started working on Wheatley's plantation on Ranongga, Kwa'ioloa's elder brother John Maesatana took up his first labor contract in Honiara, which was in the process of being built up on the remains of the us army's World War II base. Maesatana had previously worked for one the country's largest commercial operations, Lever's Pacific Plantations in Western Province (Kwa'ioloa and Burt, 1997: 42; 2012: 64). As a young man, Kwa'ioloa followed his older brother to Honiara. Through the 1970s, he moved back and forth between his home in Kwara'ae and Honiara through the 1970s; beginning in 1980, he lived continuously in town (2012: 63). Over the years, he worked in a variety of occupations: as a clerk, within a family contracting business, and as a special constable within the police force. He describes himself being in the middle of the emerging class system of Solomon Islands: neither part of the governing elite nor the "grassroots" who struggle to get any money at all, but someone who continues to struggle to make businesses work, sometimes succeeding and sometimes failing (2012: 270). Kwa'ioloa frequently foreshadows the possibility of returning to a subsistence lifestyle:

"if we finish working, we'll return home to live in the way I did as a child." (1997: 157)

Even in 2012, when his children and grandchildren had been raised almost entirely in town, Kwa' ioloa describes it as a place to make money temporarily:

8. In addition to these two edited memoirs, Burt and Kwa'ioloa have co-written an account of the life of Kwa'ioloa's father (Burt and Kwa'ioloa, 2001) and a pamphlet documenting the traditions of land ownership in Kwara'ae (Burt and Kwa'ioloa, 1992). 
"We stay in Honiara just to work, to pay school fees for the education of our children." $(2012: 63,135)$

Kwa'ioloa is like many first-generation migrants to Honiara who never intended to settle permanently. His elder brother was following long-established patterns of circular migration where young men spent months or years overseas or in other provinces (Kwa'ioloa and Burt, 1997: 41-42; see also Chapman, 1969, 1985, 1992; Bathgate, 1985; Frazer, 1985a, 1985b; Friesen, 1993); he was not necessarily seeking out a new urban life. Yet even by the 1970s it was clear to scholars that purportedly temporary sojourns in town were increasingly permanent.' Ian Frazer (1985a) for example, observed that upwardly mobile To'ambaita people of north Malaita living in Honiara seemed unlikely to return to their home villages after retirement, although most intended to do so.

By the 1990s, a generation of young people had lived all or most of their lives in Honiara and their connections to home were distinctly different than those of their parents. Christine Jourdan has tracked these changes, focusing most directly on linguistic transformations as Solomon Islands Pijin became the first language of young people raised in Honiara (Jourdan, 1989, 1990). Although many second- and third-generation migrants in town have minimal fluency in the vernacular languages of their parents, Jourdan notes that this shift has not diminished the importance of vernacular language. Even upwardly mobile youth who function almost entirely in English and Pijin may scatter a few words or phrases from their home languages as a way of marking island identity. Vernaculars have

"become marginal in the lives of many city people, [but they] keep their status as 'true' language even in the eyes of those who do not know them." (2007: 35)

These linguistic ideologies reflect a broader ambivalence about connections to rural homes as simultaneously crucial to identity but distant from ongoing experience. ${ }^{10}$

Especially in his first book, Kwa'ioloa describes his desire to live in town and his efforts to earn a living in Honiara's modern economy. In both books, however, he embraces a traditionalist stance and seeks to document his strategies for maintaining involvement in the affairs of his descent group on Kwara'ae, including in the context of long-running land disputes. $\mathrm{He}$ contributes to traditional exchanges, especially public bridewealth prestations and compensation payments, to remain significant in the lives of his kinspeople in Honiara and in Kwara'ae. Part of this approach is a matter of conviction:

"A man who is not connected to his home is a nobody. He is no longer a person." (Kwa'ioloa and Burt, 2012: 147-148)

It is also an explicit strategy for survival. Kwa'ioloa writes that a major reason he invests so much in his rural kin is that he wants to be sure that no one back home forgets about him or his sons, and that they will be welcomed when they return (2012: 135-136).

Kwa'ioloa's stance must be understood in light of the challenges of maintaining an urban household. He documents the difficulties of showing traditional hospitality in an urban household that runs primarily on cash, describing how he tries to manage unlimited demands on limited resources (2012: 64-69). Ethnographers have long documented the struggles of urban wage earners to provision households full of non-wage-earning relatives. Writing of his own experiences living in a household with people from the Polynesian atoll of Anuta in Honiara in 1983-1984, for example, Feinberg observed that:

"the more you get [of consumer goods], the faster people eat. It does not last any longer." (1996: 211)

Not only must they host kinspeople who visit town with no other means of support, but they must manage the innumerable requests for money to pay for school fees, weddings, funerals, ship fare, church buildings and many other village projects. An important aspect of maintaining connections to home places is travel during holiday periods, but high transportation costs mean it is often difficult for urban residents to travel home. The costs of maintaining connections to home places continued to increase even as employment opportunities constricted with structural adjustment policies of the late 1990s.

It is little wonder that, as Jourdan observed, by the 1990s many urbanites sought to "shape a future for themselves away from culture and tradition (kastom)" (1995: 144) - a future in which they were primarily citizens of Solomon Islands rather than people of particular ethnicities or islands. Rachel Gooberman-Hill (1999) documented the lives of Honiara residents who embraced new class identity that depended upon the suppression of ethnic loyalties and ties to extended kin - a strategy that resonated with processes elsewhere in Melanesia at the same time (see, e.g., Gewertz and Errington, 1999).

9. See Strathern (1985) on a similar process in a Papua New Guinea context.

10. Rupert Stasch has described the ongoing importance of villages for town dwellers around Melanesia: "villages are geographic figures of nostalgia for a past that is felt to have been lost in the biographical and historical present of urban life, even as urbanites' actual ties with village settings are morally ambivalent and socially fraught" (2010: 56). 
The Ethnic Tension of 1998-2003 highlighted the risk entailed by these strategies of disarticulation from rural kin. As Guadalcanal militants began to attack settlements east and west of Honiara in 1998, many residents fled first into town and then to their home provinces. People of all provinces were affected (Donner, 2002 discusses a Sikaiana settlement that was also attacked), but the majority of settlers were from Malaita province. Some settlers in peri-urban areas of Honiara organized self-defense and remained in Honiara to defend their property, but most Malaitans simply left, observing that they had homes to return to and did not need to live where they were not welcome (Stritecky, 2001). Some twenty thousand people returned to Malaita in $1999 .{ }^{11}$ Yet, not all return migrants found themselves welcomed home. Writing of rural West Kwara'ae, Gegeo and Watson Gegeo (2012) observed that many young urbanites did not speak Kwara'ae language or behave in ways that villagers found appropriate, and they were blamed for a wide range of social problems. Malaitan converts to Islam in Honiara, whom I interviewed in 2006-07, lamented the hypocrisy of their Christian neighbors and relatives back in Malaita who failed to welcome them home (McDougall, 2009: 486-487). By 2000, a Malaitan counter-militia had re-taken control of Honiara and by 2001 and 2002 many return migrants had returned to Honiara, more aware than ever of the precarity of their situation.

Kwa'ioloa takes the experiences of these return migrants as an affirmation of his traditionalist strategy. He described what happened when acquaintances returned to Malaita in 1999:

"When they reached home they went straight to the place which they thought was their land, but people there didn't want them to stay because, they said, 'You left a long time ago."' (2012: 148)

Another friend suffered a worse fate when he returned to disputed land in To'ambaita in Malaita's north. Rather than being welcomed back, he was killed - "cut up like fried chicken" (2012: 148). Yet, despite the apparent strength of his ties back home, Kwa'ioloa did not move his family back to Kwara'ae during the Ethnic Tension. After some equivocation, and consideration of the conflicting advice offered by the ghosts of both his mother and father who appeared in dreams, Kwa'ioloa decided to remain and defend his property in Honiara (2012: 209-210).

In Chief's Country, Kwa'ioloa firmly affirms his own family's rights to live in peri-urban Honiara and, more broadly, the rights of Malaitans to live on Guadalcanal. According to Kwa'ioloa, his brother and other kinsmen approached local Guadalcanal landowners around Mount Austin in the late 1950s for permission to found a settlement that would become Kobito 2 . $\mathrm{He}$ carefully names the Guadalcanal leaders who granted this permission and lists the Malaitan men who first established Honiara's settlements. The first house was filled with relatives, who gradually began building their own homes (1997: 44-45). The settlement included land for gardening to supplement low incomes, an advantage not enjoyed by many urban migrants (2012: 68). Although Kwa'ioloa describes his family's efforts to establish clear legal title for their property in Honiara, he clearly sees their customary relationship to Guadalcanal landowners as the source of their legitimate residence. He describes the relationship between his family and the landowners as one of "children" and "fathers." $\mathrm{He}$ and his family worked on behalf of the Guadalcanal landowners, inviting them to feasts, helping them with land disputes, contributing to community projects; the Guadalcanal landowners granted permission to them to use land (2012: 196-197). This account of how his family engaged with Guadalcanal landowners is not unusual: similar accounts have been documented all around northern Guadalcanal (Allen, 2013: 92; Kabutaulaka, 2001: 15; Monson, 2012: 229-37; Stritecky, 2001: 83).

More controversial than his account of his own family's right to live at Kobito 2 is Kwa'ioloa's sweeping justification of Malaitan residence on Guadalcanal lands in the terms he calls "Kwara'ae tradition." First, and perhaps most controversially, Kwa'ioloa suggests that Guadalcanal people are actually descended from Kwara'ae people, figuring Malaitans as genealogically senior to Guadalcanal people. ${ }^{12}$ Second, he argues that Malaitans were responsible for clearing all of the forest on Guadalcanal and that clearing forest has always conveyed primary rights over land. Kwa'ioloa's discussion of the work of Malaitans in clearing Guadalcanal echoes James Suafo's comments about clearing the big bush around New Mala, but fails to acknowledge the prior rights of local people in the way that James did. By describing Malaitans as "the productive, active people who did everything in Guadalcanal", Kwa'ioloa evokes ethnic stereotypes of Guadalcanal people as less industrious (2012: 195). As Matt Allen (2013: 152-154) has pointed out, Kwa'ioloa's comments echo others made by Malaitan leaders and Malaitan ex-militants who claim that Malaitans built the nation of Solomon Islands with their labor. Finally, Kwa'io-

11. At the height of the evictions in 1999-2000, approximately $10 \%$ of the entire population of Malaita overall, and up to $25 \%$ of some parts of North Malaita, was comprised of returnees from Guadalcanal (Fraenkel, 2004: 61-62).

12. Ben Burt (Kwa'ioloa and Burt, 2012: 15) acknowledges that such a claim would be contested by many Guadalcanal people. 
loa argues that Malaitan sacrifices during World War II should have been acknowledged with a large gift of pig and valuables, or a gift of land:

"This is why we have done no wrong in settling Guadalcanal land, because our fathers and grandfathers were shot dead on the island of Guadalcanal, so that the Guadalcanal people could all remain on their island." (2012: 194)

Despite these bold assertions of Malaitans' rights to live on Guadalcanal (assertions that would be contested by many Guadalcanal people), Kwa'ioloa is surprisingly sympathetic to the desire of Guadalcanal to rid themselves of strangers who had arrived without their permission. He argues that many Malaitans who arrived later in Honiara did not establish a connection to landowners in the way that he and his brothers did. Instead, they went to the Honiara Town Council or the Lands Department, which automatically issued "temporary occupation licenses" within the extended boundaries of the town without any consultations with the landowners (2012: 198; see also Foukona, 2015; Moore, 2015). Like my Malaitan interlocutors on Ranongga, Kwa'ioloa admits that Guadalcanal had a right to be angry. Again, this sentiment is not anomalous: Malaitan sympathy for the Guadalcanal cause has been widely reported (Allen, 2013: 144; Gegeo and Watson-Gegeo, 2012: 237; Stritecky, 2001: 105).

There are striking similarities in the way that both of these migrant families downplayed the legal processes that might have legitimated their residence on the land of others: New Mala might have been alienated land, but James Suafo said it belonged to the local people; settlers in Honiara might acquire Temporary Occupation Licenses, but Michael Kwa'ioloa thought everyone should engage directly with landowners. Yet there are contrasts as well between these accounts. Children who grew up in New Mala learned Ranonggan languages and married Ranonggans. Even as their ties to Malaita weakened, they really did become people of the place. In rural areas, physical labor (clearing land and planting gardens) or emotional labor (caring for local people) anchors migrants in their adopted homes in a way that it does not for urban residents. Urban life is centered not on land but on money. Local hosts may find it difficult to be hospitable if they feel overwhelmed by the sheer number of migrants drawn to town. If rural migrants depend on the hospitality of landowners, urban residents are far more dependent upon national and global economies and a government that proved unable to guarantee their security during the period of civil crisis.

\section{Conclusion: Fraught returns and urban futures}

The early years of the Ethnic Tension demonstrated the durability of trans-island ties and the value of bilocal lives. People could, and did, go home. The town families who returned to Ranongga in 1999 and 2000 while I was living there had lost their property and livelihoods, but they ruefully reflected that at least they could return home and "eat potatoes." Like the many more Malaitans who sought refuge with rural family, they realized that the conflict could have been worse. As a Solomon Islander scholar observed:

\begin{abstract}
"communities remained and indeed succeeded in acting as buffers providing the needs of their people in the absence of government services." (Nanau, 2008: 159-160)
\end{abstract}

Amidst the disorder and fear of the first years of the Ethnic Tension, some Solomon Islanders hoped that something positive would come from the de-urbanization that followed the initial violence. My Ranonggan friends complained that people (especially young men) were going to Honiara for no reason, to wander around and avoid the hard but productive work of village life - it was a sentiment echoed widely in public discourse at the time. Some hoped the conflict would be a blessing in disguise, sending home all of those hanging around town for no good reason. Even Malaitans expressed enthusiasm about returning to develop their own province. One long-term in-married resident of Ranongga told me that he was leaving Western Province because a diamond mine would soon open near his home in Malaita. His optimism was extreme, but many Malaitans believed that they should stop using their labor to develop other provinces like Guadalcanal or Western Province and should focus on developing Malaita.

These popular sentiments reflected long-standing anti-urban attitudes dating to the colonial era, when much policy sought to limit and control movement in Solomon Islands and other Pacific Island territories (Asian Development Bank, 2016: 2016-2017; Connell, 2011: 121). Such controls were only partially successful: as Craig et al. argue for Solomons, "mobile workers would not be sedentarised in rural settings" (2014: 15). Even in the post-colonial era, government planners and overseas donors have privileged rural development over urban planning, a strategy based partly on the assumption that if rural areas are properly "developed" people will stop moving to town. Unfortunately, this long-term emphasis on rural development has failed to shift commercial activity away from a few urban centers (given the nature of much rural development funding, which is focused on isolated projects rather than broad 
based infrastructure, this failure is hardly surprising). Some analysis suggests that rural poverty throughout the Pacific is deepening and must be considered a primary driver of urban migration:

"the main drivers of Pacific urban growth are interwoven with real or perceived inequalities in socioeconomic opportunities and, more recently, rising levels of rural poverty." (Asian Development Bank, 2016: 14-15)

Unsurprisingly, the majority of Honiara residents who returned "home" in the early years of Ethnic Tensions did not remain in rural villages. Many former residents of Honiara began returning soon after the Malaitan militia established control over Honiara in late 2000 and early 2001, despite insecurity in Honiara and ongoing violence in southern Guadalcanal. Honiara today has an estimated intercensus annual growth rate of $4.7 \%$, which is among the highest in the Pacific region; approximately $80 \%$ of that growth is due to ruralurban migration (Asian Development Bank, 2016: 18). People are leaving rural villages for often poor urban conditions. As of 2012, 35\% of Honiara's population lived in informal settlements, which are unplanned, largely un-serviced, and often lacking in durable housing (UN-Habitat, 2012).

Population movements during and following the Ethnic Tensions highlight a more general point: de-urbanization is not a viable solution to poor living conditions that many residents suffer in Melanesian towns. Too many townspeople have effectively "lost their passports." Scholarly and policy analysis has begun to reflect the fact that these "urban villages" (Asian Development Bank, 2016) are here to stay, and there is an urgent need for better urban planning, better support for the informal economies that sustain many poor urban families, and increased opportunity for overseas short- or long-term migration (Curtain et al., 2016; Evans, 2015; Keen and Barbara, 2016; Sharp et al., 2014; Ware, 2005). These new approaches to urban Melanesia have begun to challenge the myth that every Melanesian citizen can return to a comfortable subsistence lifestyle in a rural village, a myth that has long distracted attention from pressing problems of urban poverty.

\section{Acknowledgements}

I am grateful to the late James Suafo and his family, as well as my long-time hosts on Ranongga, for their participation in this research. I thank the Ministry of Education and Human Resource Development of the Solomon Islands Government for permission to undertake research. Funding for the original fieldwork was from an
International Dissertation Research Fellowship from the Social Science Research Council and a Small grant from the Wenner-Gren Foundation for Anthropological Research. Writing was undertaken in 2016 during a sabbatical funded by University of Western Australia while I was a visiting scholar at the School of Culture, History and Language at the College of Asia and the Pacific at the Australian National University. I thank Daniela Kraemer for comments, Ryan Schram for further leads on the idiom of the passport, and participants 2015 conference session at the European Society for Oceanists for useful feedback. I am grateful to Christine Jourdan, Lamont Lindstrom, and three anonymous reviewers for their suggestions for improvement.

\section{REFERENCES}

Akin David W., 1999. Compensation and the Melanesian State: Why the Kwaio Keep Claiming, The Contemporary Pacific 11, pp. 35-67.

-, 2013. Colonialism, Maasina Rule, and the Origins of Malaitan Kastom, Honolulu, University of Hawai'i Press.

Allen Matthew G., 2013. Greed and Grievance: Ex-Militants' Perspectives on the Conflict in Solomon Islands, 1998-2003, University of Hawai'i Press, Honolulu.

Asian Development Bank, 2016. The emergence of Pacific urban villages: Urbanization trends in the Pacific Islands, Madaluyong City, Philippines, Asian Development Bank (retrieved 20 August 2017 from https://www. adb.org/publications/emergence-pacific-urban-villages).

BaIley Rochelle and Sharon Wells, 2017.Temporary Labour Schemes, the New Avenue of Social Mobility: Case Study Vanuatu, In Brief Series 2017/21, Acton, ACT Australian National University (retrieved 4 September 2017 from http://ssgm.bellschool.anu.edu.au/sites/default/files/publications/attachments/2017-08/ ib_2017_21_baileywells.pdf).

Bathgate Murray, 1985. Movement Processes from Precontact to Contemporary Times: The Ndi-Nggai, West Guadalcanal, Solomon Islands, in M. Chapman and R. M. Prothero (eds), Circulation in Population Movement: Substance and Concepts from the Melanesian Case, London, Routledge \& Kegan Paul, pp. 83-118.

Bellam Michael E. P., 1970. The Colonial City: Honiara, a Pacific Islands Case Study, Pacific Viewpoint 72, pp. 66-96. 
Bedford Richard and Graham Hugo, 2012. Population Movement in the Pacific: A Perspective on Future Prospects, Wellington, NZ, Labour and Immigration Research Center (retrieved 4 August 2016 from https://www.border.gov.au/ ReportsandPublications/Documents/research/ pacific-population-report.pdf).

Bennetr Judith A., 1987. Wealth of the Solomons: A History of a Pacific Archipelago 18001978, Honolulu, University of Hawai'i Press.

Burt Ben, 1994. Tradition and Christianity: The Colonial Transformation of a Solomon Islands Society, Philadelphia, Harwood Academic Publishers.

Burt Ben and Michael KwA'IOlOA, 1992. Falafala ana Ano-i Kwara'ae/The tradition of land in Kwara'ae, Suva, Fiji, Institution of Pacific Studies and Honiara Center, University of the South Pacific.

—, 2001. A Solomon Islands chronicle: as told by Samuel Alasa'a, London, British Museum.

Chapman Murray, 1969. A Population Study in South Guadalcanal: Some Results and Implications, Oceania 11, pp. 119-147.

—, 1985. Me Go 'Walkabout,' You Too?, in M. Chapman and R. M. Prothero (eds), Circulation in Population Movement: Substance and Concepts from the Melanesian Case, London, Routledge \& Kegan Paul, pp. 429-443.

-, 1992. Population Movement: Free or Constrained? in R. Crocombe and E. Tuza (eds), Independence, Dependence, Interdependence: The First 10 Years of Solomon Islands Independence, University of the South Pacific, Suva, Fiji, pp. 75-97.

Connell John, 2011. Elephants in the Pacific? Pacific Urbanization and its Discontents, Asia Pacific Viewpoint 52, pp. 121-135.

Corris Peter, 1973. Passage, Port and Plantation: A History of Solomon Islands Labour Migration 1870-1914, Melbourne University Press, Melbourne.

Craig David, Richard Bedford, David Gegeo, Patricia Rodi, Rebecca Miller and Ward Friesen, 2014. Labour Mobility and Diaspora: An Overview of Solomon Islands' Historical Regulatory Experience, 1850s-2013, NIDEA Working Papers, Waikato, University of Waikato, National Institute of Demographic and Economic Analysis (accessed 4 August 2016 from http://researchcommons.waikato. ac.nz/handle/10289/8586).

Curtain Richard, Matthew Dornan, Jesse Doyle and Stephen Howes, 2016. Labour
Mobility: The Ten Billion Dollar Prize, Pacific Possible Series, Australian National University and The World Bank (retrieved 4 August 2016 from http://pubdocs.worldbank.org/ en/555421468204932199/labour-mobility-pacific-possible.pdf).

Doherty Ben, 2017 (3 August). Hungry, poor, exploited: alarm over Australia's import of farm workers, The Guardian (retrieved 1 September 2017 from https://www.theguardian. com/global-development/2017/aug/03/hungry-poor-exploited-alarm-over-australias-import-of-farm-workers?CMP=share_btn_link).

Donner William W., 2002. Rice and tea, fish and taro: Sikaiana migration to Honiara, $\mathrm{Pa}$ cific Studies 25 (1/2), pp. 23-44.

Evans Daniel, 2015. Show Me the Selen: A Fiscal Snapshot of Honiara, Solomon Islands, SSGM In Brief Series 2015/56, Acton, ACT Australian National University (retrieved 4 August 2016 from http://bellschool.anu.edu. au/experts-publications/publications/4138/ show-me-selen-fiscal-snapshot-honiara-solomon-islands).

Feinberg Richard, 1996. Outer Islanders and urban resettlement in the Salomon Islands: the case of Anutans on Guadalcanal, Journal de la Société des Océanistes 103, pp. 207-217 (http:// www.persee.fr/doc/jso_0300-953x_1996_ num_103_2_1990).

Foukona Joseph, 2015. Urban Land in Honiara: Strategies and Rights to the City, The Journal of Pacific History 50, pp. 504-518.

Fraenkel Jon, 2004. The Manipulation of Custom: From Uprising to Intervention in the Solomon Islands, Wellington, NZ, Victoria University Press.

Frazer Ian, 1985a. Circulation and the Growth of Urban Employment Amongst the To'ambaita, Solomon Islands, in M. Chapman and R. M. Prothero (eds), Circulation in Population Movement: Substance and Concepts from the Melanesian Case, London, Routledge \& Kegan Paul, pp. 225-248.

—, 1985b. Walkabout and Urban Movement: A Melanesian Case Study, Pacific Viewpoint 26, pp. 185-205.

Friesen Ward, 1993. Melanesian Economy on the Periphery: Migration and Village Economy in Choiseul, Pacific Viewpoint 34, pp. 193-214.

Gegeo David Welchman, 2001. Cultural Rupture and Indigeneity: The Challenge of (Re) Visioning "Place" in the Pacific, The Contemporary Pacific 13, pp. 291-507. 
Gegeo David Welchman and Karen Ann WaTson-Gegeo, 2012 ( $2^{\text {nd }}$ ed.). The Critical Villager Revisited: Continuing Transformations of Language and Education in Solomon Islands, in J. W. Trollefson (ed.), Language Policies in Education: Critical Issues, New York, Routledge, pp. 233-252.

Gewertz Deborah B. and Frederick Karl ErRINGTON, 1999. Emerging Class in Papua New Guinea: The Telling of Difference, Cambridge, Cambridge University Press.

Glick-Shiller Nina Glick, Linda BAsCH and Cristina Blanc-Szanton, 1991. Towards a transnational perspective on migration: race, class, ethnicity, and nationalism reconsidered: [proceedings of a workshop with the same title, held on may 3-4, 1990 at the New York Academy of Sciences], New York, New York Academy of Sciences.

Goddard Michael, 2005. The Unseen City: Anthropological Perspectives on Port Moresby, Papua New Guinea, Canberra, Pandanas Books, Research School of Pacific and Asian Studies.

-, 2010a. About Moresby, in M. Goddard (ed.), Villagers and the City: Melanesian Experiences of Port Moresby, Papua New Guinea, Wantage, uK, Sean Kingston, pp. 1-18.

—, 2010b. Heat and History: Moresby and the Motu-Koita, in M. Goddard (ed.), Villagers and the City: Melanesian Experiences of Port Moresby, Papua New Guinea, Wantage, uK, Sean Kingston, pp. 19-46.

Hermant Norman (reporter), 2016. Seasonal farm workers receiving as little as $\$ 9$ a week after deductions, investigation reveals. 730, television program, Australian Broadcasting Corporation, 24 February 2016 (retrieved 4 September 2017 from http://www.abc.net. $\mathrm{au} / 7.30 /$ content/2015/s4413998.htm).

Hugo Graham and Richard Bedford, 2013. Pacific Islands Migration $18^{\text {th }}$ Century to Present, in I. Ness (ed.), The Encyclopedia of Global Human Migration, Wiley, United Kingdom, pp. 2358-2373.

Jourdan Christine, 1989. Nativization and Anglicization in Solomon Islands Pijin, World Englishes 8, pp. 25-35.

-, 1990. Solomons Pijin: An Unrecognized National Language, in R. B. Baldauf and A. Luke (eds), Language Planning and Education in Australasia and the South Pacific, Multilingual Matters, Clevedon, England, pp. 166-181.

-, 1995. Stepping-Stones to National Consciousness: The Solomon Islands Case, in
R. J. Foster (ed.), Nation Making: Emergent Identities in Postcolonial Melanesia, Ann Arbor, Michigan University Press, pp. 127-150.

-, 1998. Les hommes non-lieux : enracinement culturel des jeunes dans l'espace urbain d'Honiara (îles Salomon), in G. Dominique, M. Seysset et A. Walter (éds), Le voyage inachevé... À Joël Bonnemaison, Paris, ORstom, Prodig, pp. 423-430.

—, 2007. Linguistic Paths to Urban Self in Postcolonial Solomon Islands, in M. Makihara and B.B. Schieffelin (eds), Consequences of Contact: Language Ideologies and Sociocultural Transformations in Pacific Societies, Oxford, Oxford University Press, pp. 30-48.

Kabutaulaka Tarcisius Tara, 2001. Beyond Ethnicity: The Political Economy of the Guadalcanal Crisis in Solomon Islands, State, Society and Governance in Melanesia Discussion Paper, 01/01, Canberra, АСт, Research School of Pacific and Asian Studies, Australian National University (retrieved 15 November 2005 from http://eprints.anu.edu.au/archive/00001992/).

Keen Meg and Julien Barbara, 2016. Pacific Urbanization: Changing Times, Devpolicy Blog from the Development Policy Centre, Canberra (retrieved 31 July 2016 from http:// devpolicy.org/pacific-urbanisation-changing-times-20160225/).

Keesing Roger M., 1992. Custom and Confrontation: The Kwaio Struggle for Autonomy, Chicago, University of Chicago Press.

Keesing Roger M. and Peter Corris, 1980. Lightning Meets the West Wind: The Malaita Massacre, Melbourne, Oxford University Press.

Kraemer Daniela, 2013. Planting Roots, Making Place: An Ethnography of Young Men in Port Vila, Vanuatu, Department of Anthropology, PhD Thesis, Social Anthropology, The London School of Economics and Political Science.

Krose Sarah, 2015. Same people, different people: Recognition, knowledge, and the (re) construstion of relationships in Bilua, Vella Lavella, PhD Thesis, Anthropology, The University of Auckland.

Kwa'Ioloa Michael and Ben Burt, 1997. Living Tradition: A Changing Life in the Solomon Islands, London, British Museum Press.

-, 2012. The Chief's Country, Brisbane, University of Queensland Press.

LindSTrom Lamont, 2011. Urbane Tannese: Local Perspectives on Settlement Life in Port 
Vila, Journal de la Société des Océanistes 130, pp. 255-266 (http://jso.revues.org/6461).

—, 2012. Vanuatu Migrant Lives in Village and Town, Ethnology: An International Journal of Cultural and Social Anthropology 50, pp. 1-15.

Mcdougall Debra, 2009. Becoming Sinless: Converting to Islam in the Christian Solomon Islands, American Anthropologist 111, pp. 480-491.

-, 2015. Customary Authority and State Withdrawal in Solomon Islands: Resilience or Tenacity? The Journal of Pacific History 50, pp. 450-472.

-, 2016. Engaging with Strangers: Love and Violence in the Rural Solomon Islands, New York, Berghahn Books.

Monson Rebecca, 2012. Hu Nao Save Tok? Women, Men and Land: Negotiating Property and Authority in Solomon Islands, PhD Thesis, Law, The Australian National University.

—, 2015. From Taovia to Trustee: Urbanization, Land Disputes and Social Differentiation in Kakabona, The Journal of Pacific History 50, pp. 437-449.

Moore Clive, 2004. Happy Isles in Crisis: The Historical Causes for a Failing State in Solomon Islands, 1998-2004, Canberra, Аст, Asia Pacific Press.

-, 2007. The Misappropriation of Malaitan Labour: Historical Origins of the Recent Solomon Islands Crisis, Journal of Pacific History 42, pp. 211-232.

—, 2015. Honiara: Arrival City and Pacific Hybrid Living Space, The Journal of Pacific History 50, pp. 419-436.

-, 2017. Making Mala: Malaita in Solomon Islands, 1870s-1930s, Canberra, ACT, ANU EPress (doi: http://dx.doi.org/10.22459/MM.04.2017).

Nanau Gordon Leua, 2008. Intervention and Nation-Bulding in Solomon Islands: Local Responses, in G. Fry and T. T. Kabutaulaka (eds), Intervention and State-Building in the Pacific: The Legitimacy of 'Cooperative Intervention', Manchester, Manchester University Press, pp. 149-162.

SCales Ian, 2007. The Coup Nobody Noticed: The Solomon Islands Western State Move- ment in 2000, Journal of Pacific History 42, pp. 187-209.

Sharp Tim, John Cox, Ceridwen Spark, Stephanie Lusby and Michelle Rooney, 2015. The Formal, the Informal, and the Precarious: Making a Living in Urban Papua New Guinea, in SSGM Discussion Paper Series. SSGM In Brief Series 2015/56, Acton, ACт Australian National University (retrieved 15 December 2015 from http://ips.cap.anu.edu.au/sites/ default/files/DP\%202015_2\%20Sharp\%20 Cox\%20Spark\%20Lusby\%20Rooney.pdf).

Solomon Islands Statistics Office, 2012. Report on 2009 Population and Housing Census: Basic Tables and Census Description, Honiara, Solomon Islands Government, vols. 1-2 (retrieved 5 Feb 2015 from http://www.spc. int/prism/solomons/).

Stasch Rupert, 2010. The Category "Village" in Melanesian Social Worlds: Some Theoretical and Methodological Possibilities, Paideuma 56, pp. 41-62.

Stritecky Jolene Marie, 2001. Through a Moral Lens: Morality, Violence, and Empathy in Solomon Islands, PhD Thesis, Anthropology, University of Iowa.

Strathern Marilyn, 1985. The Disconcerting Tie: Attitudes of Hagen Migrants toward "Home", in M. Chapman and R. M. Prothero (eds), Circulation in Population Movement: Substance and Concepts from the Melanesian Case, London, Routledge \& Kegan Paul, pp. 360-376.

United Nations - Habitat, 2012. Solomon Islands: Honiara urban profile, Nairobi, Kenya, United Nations Human Settlements Program (retrieved 10 August 2017 from http://www. unhabitat.org).

VAn Heekeren Deborah, 2010. Cracks in the Road: Trying the Moral Limits of Capitalism in a Vula'a Village, in M. Goddard (ed.), Villagers and the City: Melanesian Experiences of Port Moresby, Papua New Guinea, Wantage, uK, Sean Kingston, pp. 47-74.

Ware Helen, 2005. Demography, Migration and Conflict in the Pacific, Journal of Peace Research 42, pp. 435-454. 